\title{
Study on Colonialism of English and Spanish Language
}

\author{
Bangjie Chen \\ Tianjin University \\ Tianjin
}

\begin{abstract}
Language colonialism is a cultural phenomenon that the language of colonizers is imposed on people in the colonies and gradually becomes the dominant language. The essence of language colonialism is a deliberate attempt to eliminate the inferior culture. As the core of cultural colonialism, language colonialism has played a significant role in the activities of English and Spanish colonization from 16 century to 18 century. With the advancement of global economy and science and technology, language colonialism has helped the integration of different nations and cultures to some extent. However, in the process of language colonialism, many countries and nations were forced to abandon their own languages and cultures. This article explores the colonialism of English and Spanish language from the perspective of the background and motivation of language colonialism and the language policies in the America as well as the influence on the post-colonial people and culture.
\end{abstract}

Keywords: language colonialism, Native American language, language policy

\section{Introduction}

Language colonialism is the linguistic counterpart of the "European centralism" in the colonial period. Those who believed that they have the most advanced culture were always keen to carry forward their culture and hoped their own language can spread in places where human footprints set on [1]. Facing the resistance of the Native Americans, the colonizers adopted the means from violent conquest to language assimilation to consolidate their rule and the colonialism of language is crucial to build authority among colonized people. For one thing, in the early times of colonization, the Spanish king ordered the promotion of Spanish in the Americas. In the new environment, Spanish has been widely used and it has grown rapidly. By the end of the 18th and early 19th centuries, Spanish with a strong American feature had become the lingua franca of the entire colony. In the later independence movement in the Americas, Spanish and English also became a political weapon of national unity. For another, since 1607, the United Kingdom has become the sovereign state of the North Americas and then lots of immigrants came to this land, increasing the population of the America and bringing different religious beliefs and cultural languages. Although the colonial rule came to an end after the American Revolution, the language colonialism of English still moved on because the two groups were bound together by English, a shared tongue. The implementation of various language policies has continued and the descendants of ethnic groups have integrated into an English-dominated society.

\subsection{Anomaly's is Of The Intention Of Language Colonialism}

There are a couple of possible motivations that explain the language colonialism of English and Spanish. Language, as a tool of human communication, in a sense is a symbol of people's identity. When a certain group is more powerful than others, its language has a higher status. In the colonial society, the unbalanced socio-political status of the colonizers and of the colonized people led to an unequal position of language. To distinguish the powerful and powerless classes, the colonizers had to draw a clear line between the ruler and the ruled. By instituting a power divide along with linguistic lines they produced social fissures which continued to have influence in contemporary America. Aligned with the ruling elite in colonial times, English and Spanish became powerful languages and an effective tool of colonial rule.

If the colonization of territory by arms is a little bit barbarous, the colonization of language seems a relatively "civilized" way to impose the colonized people into speaking their language and exert the influence of their culture. By establishing the unequal relationship between the colonial language and the colonized language in terms of ideology, colonial oppressors established their absolute domination and their status is maintained and consolidated. Language colonialism is both the cause of colonial rule and the product of it. 
Due to the power of the colonizers and the resistance of the colonized people, the process of language colonialism was sometimes full of blood and death. Gradually, violence worked and the resistance to it weakened. With time going by, the foreign language was seen as a truly high-level language and was endowed with so-called advantages that are superior to the native language. In the colony, it was one of the most important strategies to make the colonized people reconstruct their subjectivity and surrender to the colonists from inside out and learn a new language. In 1806, when the British overthrew the colonial rule of Netherlands in South Africa, the British colonists declared that English is the official language, and anyone who works in government sector has to learn and use English.

In order to bring language and culture, religious beliefs and values of the colonial states to the colony as well as to suppress the local cultural freedom, the rulers take language colonialism as a major method to exert cultural colonialism, the unequal cultural exchange which a strong culture promote its values and ideology to a weak culture through its economic, political, military, and media superiority. We can say that cultural colonialism is the root of language colonialism since the most complicated and insidious form of colonialism is cultural colonialism and the most direct way to realize the cultural colonialism is language colonialism. Therefore, colonialism, cultural colonialism and language colonialism constitute a progressive and complementary colonial politics. Western countries separated the local people from the native language through language colonialism, forming a unique colonial cultural and political phenomenon - spiritual colonialism [2].

Furthermore, the religious motivation of English and Spanish language colonialism has always much in common. The Christianization of the American colonies was a complement to colonial rule and the spirit fetter to strengthen the colonial dependence on the colonial state. Converting the local pagans to Christianity is an example of spiritual colonization since the promotion of religion is a typical vehicle to affect the spiritual life of people. After conquering the Inca Empire, Spain began to spread the teachings of Christianity which completely changed the traditional culture of the indigenous people. The missionaries built Christian churches in the Native American communities and established monasteries as well as opened church schools [3]. Following Spain's vigorous promotion of Catholicism in South America, Protestants in the UK also began to look for new soil for the development of Protestantism in North America. The Reformation that broke out in Germany in the 16th century also became one of the decisive forces shaping the history of the Americas. To pursue religious ideals and shelters from the persecution as well as to enlarge the room for survival and development, the pilgrims came to America. They imposed Christianity on local people to civilize other nations with the gospel of God and bring them Christian faith. Therefore, churches and schools have a paramount position in the colonial management system because the promotion of Christian faith cannot continue without sermon and education. In order to promote the spread of religion, the authorities must take certain measures to enable the colonized people to learn their own language and it was an effective means of making local people understand their doctrine better. The America became an ideal place to pursue religious freedom and establish a kingdom of Christ. It can be said that the role of religious expansion is enormous in language colonialism.

The language and religious control adopted by the colonizers has enabled their ideology and values to be instilled and accepted in the Americas and both languages have also been developed to some extent.

\section{The Language Policy of English and Spanish in Colonial Times}

Language policy of English and Spanish in the colonial period both reflected the linguistic imperialism because the colonialism of English in the North America and the colonialism of Spanish in South America were based on restraint and sacrifice of the language of other ethnic minorities. Unity and standardization are the orientation of colonial language policy. With the arrival of colonizers in the 16 centuries, the Native American culture and language were deliberately and completely broken at the same time. What's more, the circle of language colonialism expanded to other ethnic groups. Before 1775, German immigrants have already been forced to receive education in English schools and also to black Africans, the law explicitly prohibited the teaching of their words and they had no right to use and inherit their native language. Although the ethnic groups of the Americas tried to maintain their own cultural traditions, they still cannot stop the pace of language integration [4].Furthermore, the language policy combined with certain political factors. The early English colonizers in North America became political and cultural elites and regional leaders, but specific group like local noblemen had to learn Spanish if they wanted to serve the colonial machinery at lower administrative levels. Affiliated ideologically and practically with the educational system and government, these two languages came to acquire sovereign status within a complex language hierarchy. 
To curb the development of indigenous languages Spanish also took the policy of language assimilation in the American colonies, excluding languages that are in a weak position. Taking one colony of Spain as an example, with the arrival of Spanish colonizers, Quechua, the official language chosen by the Inca Empire was replaced by Spanish. The conquered people stopped using Quechua and instead they used the language of each tribe when they realized that the language unity was at the expense of abolishing their official language and the diversity of indigenous languages that the Incas tried to eliminate reappeared [5].The Native American languages which had no written languages could only retreat in the face of Spanish, an advanced language with written traditions and mandatory writing culture. In this way, the Spanish colonial policy and promotion of Christianity implemented smoothly in virtue of power and economic advantages, and therefore accelerated the extinction of the Peruvian Indian nation and its language. The language policies of English and Spanish enforced and enacted a homogenizing gaze that glosses over ideological pluralism and language complexity in the America. The colonial language policies they adopted reflected the essence of the language imperialism.

\section{The Reasons of Effective colonialism of English and Spanish language}

From the perspective of Demographic, the successful language colonialism of English and Spanish was attributed to the population migration guided by the government since people are the essential medium of language communication. Sociolinguistics believes that communication partly leads to the spread of language. The frequent migration contributes to connection among different communities and more widely using of language in certain time and space. Out of the need for labor force to develop natural resources in the Americas and the drastic reduction of the population of aboriginal Indians, Spain and Britain have encouraged people to emigrate to the New World in various aspects. During 1550 to 1750, along with the colonization of west European countries in America, trans-continental emigration emerges and North Atlantic migration system is vigorous over the next few years. A large number of free and non-free immigrants flooded into the America to find new opportunities. The frequent migration of the two countries has led to the wide spread of English and Spanish language in the America.

Conversely, for the Netherlands which is also a colonial country, its language did not acquire the same influence as English and Spanish did because of the infrequent trans-continental emigration since the population base of the Netherlands was small and expanding colonies overseas drained large numbers of people. In 1600, the population of the Netherlands was only 1.5 million, and by 1800 it was only 2.1 million. The slow growth of population limited the trans-continental emigration and accordingly limited the spread of Dutch in more areas. In addition, the successful colonialism of language has a close relationship with culture. Culture is the product of history, which is written by language and language is the bond linking nation with culture so that in many cases, we cannot ignore the existence of culture when we talk about language. The Jews have experienced many calamities, but the Hebrew language remains until today because the foundation of religious belief and national culture. As the literary language of Jew, Hebrew never stopped its development and became a necessary prerequisite to the continuity and revival of a nation and culture in return. Unfortunately, the geographical isolation of the America impeded its exchange with other nations, resulting in the stagnation of the development of American civilization.

Before Spanish conquered Central and South America, the Mayan civilization, which is the only one having written languages had gradually declined in this land while the Aztec civilization and the Inca civilization are at their most prosperous times. European colonizers completely destroyed the two civilizations and the remnants of the Mayan civilization, uprooted the local culture with force and replaced it with its own culture. The reason that Native American languages were easily replaced is the fragility of its culture without a powerful and unified foundation. On the contrary, if there has been a unified culture foundation in the colony already, language colonialism will be slower. The language itself is also an important reason. The unification and standardization of any language is a long course of history. When Britain and Spain started their colonial activities, the respective language of them has moved toward mature compared with other European countries while the colonies still lacked a unified language and stable government. The Native American linguistic landscape was incredibly diverse and rich that it was very difficult for a single language to take over the dominant position and linguistic differences between various tribes interfered with the normalization of language. When newcomers arrived, language with high degree of standardization also came to this land, making use of its advantages to influence the local language and consequently it grasped the dominance of education and media in the colonies and influenced the local people all round. Peru, for instance, a multi-ethnic and multi-lingual country, has 14 language communities distributed in various regions and some communities also have dialects. 
The Spanish colonizers conquered this place and tried to promote their own language, but as with all foreign things it met with resistance. However, due to the relative primitiveness and backwardness of the indigenous languages them self, the Spanish language was finally on this land.

Language is a place of struggle between the colony and the metropolitan state, where the victorious party has a dominant position and the losing party can only be assimilated. It is clear that Peru, which is dominated by Spanish, has failed in the language struggle compared to Tanzania, a British colony in Africa, which successfully selected and promoted the indigenous Swahili as the official language.

\section{The influence of Language Colonialism of English and Spanish Language}

Language colonialism has promoted the development of culture, science, technology, and religious beliefs in the Americas, in a sense it pushed forward the development of the American and even human civilization. However, it also means the painful sacrifice of the colonized people. They destroyed the social mechanisms of indigenous nations, eliminated indigenous civilizations, and ended the history of indigenous culture which could not have an equal dialogue with the foreign culture and therefore gradually declined on account of the loss of language rights. The consequences were serious. Firstly, it has destroyed the psychological basis of the local people since language colonialism dissociated individual emotions from the social environment. It's painful for anyone who can't express their emotions and feelings freely with their own language. Secondly, it has caused the American Indian culture to break and accelerated the decline of Indian language. Language colonialism, to some extent a cultural colonialism, deprived the cultural value of the native language and separates the relationship between the national language and the realistic literature. Today it is almost impossible to revive the glorious civilizations since most of the native languages have been assimilated or replaced. The colonized people can only understand the world from the perspective of European language and culture, and the output of their own culture was also hindered.

On the one hand, the aboriginal languages have gradually died out since people use them less and less. The indigenous languages have lost its right to realize an equal exchange with foreign cultures and therefore are gradually disappearing.

It is language that maintains the moral, aesthetic and other values in a social community because language is the carrier of culture and the memory of national history. The generation and development of language has a close connection with national culture and thus the extinction of national languages hook the foundations of cultural development and forced weak culture to imitate strong culture and be assimilated by it. Regardless of the centuries passed, the wounds of language colonialism which ruins the basis of cultural development of the Indian nations remain fresh.

Also, in the post-colonial period, the "otherness" who was not colonizer had suffered aphasia which caused by the decline of the mother tongue was formed under the oppression of colonial rule, and the "otherness" was deprived of the right to speak [6]. In the colonial era, the colonial people were forced to use the language of the colonizers and in some places the colonial language even became the official language which caused the marginalization of the indigenous languages. At the same time, the indigenous literature and culture disappeared while foreign languages were widely used in post-colonial novels and became the mainstream of literature.

\section{Conclusion}

The language colonialism of English and Spanish is arguably the most successful compared with many other colonial countries which did not get the profound influence like the formers. During the colonization of over three hundred years, English and Spanish are firmly rooted in the American nations and integrated with colonized languages and then a new culture came out in America. Its influence on ideological dissemination was even greater than that of indigenous languages. The connection between language and America's colonial past is still alive and well. 


\section{References}

Xing Lijuan. The influence of language colonialism on world linguistic culture[J].Lanzhou Journal. 2008(S1):233-234.

Tao Jiajun. Language, Art and Cultural Politics: Speculations on NgugiThiong'o's Anti-colonial Thought[J].Foreign Literature.2006(04):59-65.

Wang Yaping. The Political Role of Catholic Missionary Activities in the Spanish Colonies in the 16th Century[J].historical study. 1992(05):154-162.

Fan Linjuan, Zhou Yuzhong. Review of American Colonial Language Policy [J]. Journal of Ningxia University (Humanities and Social Sciences) 2007 (06) : 153-155.

PuZhonglian. The Choice of Official Language Policy: From Native Language to Colonial Language: A Study of the History and Current Situation of Peruvian Language Policy [J]. World Ethno-National Studies. 1999 (03) : 56-66.

Wei Miao. Decline and Reconstruction_-On the Language Imagery in Postcolonial Novels [J]. Journal of Yuncheng University, 2014 (03) : 70-72. 